\title{
The Case History in Medieval Islamic Medical Literature: Tajārib and Mujarrabāt as Source
}

\author{
CRISTINA ÁLVAREZ MILLÁN*
}

Knowledge of medieval Islamic medical practice has traditionally been based on the analysis of learned treatises. However, a comparison of the therapeutic advice advocated in formal treatises with treatments prescribed to patients has shown that the appeal to theory was to a large extent neglected in practice and, therefore, that theoretical works are not a reliable account of reality. ${ }^{1}$ From this perspective, case histories may prove to be an invaluable source for medical historians studying medical practice in medieval Islam. Yet, case histories - as well as prescriptions for actual patients, clinical observations, and medical anecdotes-are, none the less, literary sources, and we may well stumble on the same stone twice as we did when studying theoretical treatises regardless of literary and social contexts. The purpose of this paper is mainly to question whether the varying categories of clinical accounts can be treated as reliable guides to medieval Islamic clinical practice. The question of whether medieval Islamic medical authors deliberately followed a particular style of clinical account common among ancient

(C) Cristina Álvarez Millán 2010

* Cristina Álvarez Millán, PhD, Departamento de Historia Medieval, Facultad de Geografía e Historia, UNED, Edificio de Humanidades, Paseo Senda del Rey, 7, 28040 Madrid, Spain.

This paper arose out of my research project on $E l$ relato clínico en la literatura médica islámica medieval, funded by the Dirección General de Investigación Científica (Ministerio de Educación y Cultura). Many of the ideas hinted at or expressed here, also owe much to a previous research project on $A l-R \bar{a} z \bar{\imath}$ 's Kitāb al-Tajārib. Edition and Study, funded by the Wellcome Trust (Ref. num.: 045064/Z/95). Both research projects were carried out at the Academic Unit of the Wellcome Institute for the History of Medicine (now the Wellcome Trust Centre for the History of Medicine at UCL) in London. A revision of an early draft of this paper was made possible thanks to a Wellcome Travel Grant (Ref. num. 062327/Z/00). The final revision was undertaken thanks to a University Award granted by the Spanish Ministerio de Ciencia y Tecnología (Programa Ramón y Cajal) at the Universidad Nacional de Educación a Distancia (UNED). I am particularly grateful to Emilie Savage-Smith, Michael McVaugh, Vivian Nutton, Peregrine Horden, Selma Tibi, and Lawrence I Conrad for reading subsequent versions of this work and suggesting helpful comments. Caroline
Tonson-Rye and Gonzalo Carrasco have also assisted me with the English text. However, any mistake or misinterpretation is exclusively mine.

${ }^{1}$ See Cristina Álvarez Millán, 'Practice versus theory: tenth-century case histories from the Islamic Middle East', Soc. Hist. Med., 2000, 13(2): 293-306, (special issue, Peregrine Horden and Emilie SavageSmith (guest eds), The year 1000: medical practice at the end of the first millenium). The same applies to medieval Islamic surgical treatises traditionally praised by scholarly literature, which have been proved to follow a literary tradition and which contain a number of statements suggesting that the Islamic physicians who wrote them never carried out-and never heard of anyone who had performed-some of the invasive surgical techniques described in their works. See Emilie Savage-Smith, 'The practice of surgery in Islamic lands: myth and reality', Soc. Hist. Med., 2000, 13(2): 307-21; idem, 'The exchange of medical and surgical ideas between Europe and Islam', in John A C Greppin, Emilie Savage-Smith and John L Gueriguian (eds), The diffusion of GrecoRoman medicine into the Middle East and the Caucasus, Delmar, NY, Caravan Books, 1999, pp. 27-55; idem, 'Tashrīh', The encyclopaedia of Islam, new ed., 11 vols, Leiden, Brill, 1960-2002, vol. 10 , pp. 354-6. 


\section{Cristina Álvarez Millán}

Greco-Roman patterns, and whether they deployed case histories to illustrate the practice of medicine or to build up their reputation in the medical market-place, has been addressed elsewhere. ${ }^{2}$ A comparison of case histories by Abu Bakr Muhammad b. Zakarīyā' al-Rāzī (d. 313/925) with Greco-Roman models showed that this particular Islamic physician used the case history as a tool for medical instruction rather than for self-promotion. However, the question of whether al-Rāzì's clinical accounts were representative within medieval Islamic medical literature remains open. As demonstrated below, an analysis of a wider range of sources shows that medieval Islamic medical writers certainly used scientific rhetoric for self-representation as well as persuasive strategies for self-promotion like those found in Galen's case histories. Consequently, the use of literary devices to stress features other than the interpretation of symptoms, prognosis and therapy raises the issue mentioned above: do medieval Islamic case histories serve as documentary evidence of actual medical practice? With the aid of a wider scope of materials than those by al-Rāzì, I shall attempt to draw attention to the dangers of reading case histories-like theoretical treatises - too literally, and to explore the historical value of clinical records in assessing a particular physician's everyday practice.

In order to provide as broad a picture as possible of the clinical account in medieval Islamic medical literature, I have divided this paper into three parts. The first section provides an overview of collections of case histories and medical experiences as a literary genre. In the second, case histories taken from different medieval Islamic authors will show the various purposes of clinical accounts. As far as the details of practice are concerned, I will let case histories speak for themselves, focusing instead on their wording and style, and their literary or social contexts so as to ascertain the author's agenda. In the third section, I shall analyse case histories attributed to the well-known Islamic physician Ibn Sīnā, known in the western medical tradition as Avicenna (d. 428/1037). A study of his recorded clinical experience will show that his medical theory and practice operated in different spheres, suggesting that our present consideration of his excellence as a clinician is supported by historical assumptions rather than by a critical analysis of sources.

\section{Tajärib and Mujarrabāt as a Literary Medical Genre}

The Arabic words tajārib and mujarrabāt were used by medieval Islamic scholars to refer to the physician's case histories and medical experiences, that is, remedies or treatments presumably applied in real cases. Although clinical accounts appear scattered in theoretical treatises, medieval Islamic medical literature also presents a few collections specifically concerned with that material, such as those by Abū Bakr Muhammad b. Zakarīyā', al-Rāzī in tenth-century Iraq and western Iran, or Abū Ja'far Ahmad b. 'İsá al-Hāshimī and Abū l-'Alā' Zuhr in eleventh and twelfth-century al-Andalus respectively, ${ }^{3}$ all of

\footnotetext{
${ }^{2}$ Cristina Álvarez Millán, 'Graeco-Roman case histories and their influence on medieval Islamic clinical accounts', Soc. Hist. Med., 1999, 12 (1): 19-43.

${ }^{3}$ Al-Rāzī, Kitāb al-Tajārib, Topkapi Saray Library, Istanbul, Col. Ahmed III, MS. 1975; Ahmad b. 'Īsà al-Hāšimī, Kitāa al-Mầālis fì l-tibb, ed.
}

S Kaddouri, Madrid, CSIC, 2005; Abū 1-'Alā' Zuhr, Kitāb al-Muŷarrabāt, ed. with Spanish transl. and study by Cristina Álvarez Millán, Madrid, CSIC, 1994. An edition of the first work has been published by Khālid Harbī (Kitāb al-Tajārib li-Ab̄̄ Bakr Muhammad̀ b. Zakarīyā' al-Rāzī, Alexandria, Dār 


\section{The Case History in Medieval Islamic Medical Literature}

which were collected posthumously and circulated as independent works. ${ }^{4}$ However, for a long time, scholars assumed that treatises with titles including the term tajärib or mujarrabāt (experiences) contained material of a magical character.

The confusion over this literature comes from the association of those Arabic words with the expression mujarrab which, employed throughout medieval writings as a cliché at the end of magical recipes, means "tried" or "tested". This association probably arose out of Lynn Thorndike's study on 'Experiments and Secrets of Galen, Rasis, and Others'. ${ }^{5}$ Much of his study was based on insufficient evidence, for it involved a partial analysis of Latin texts, either of uncertain attribution and difficult identification or considered to be translations of Arabic sources whose contents he did not personally know and collate. More importantly, in the absence of available Arabic sources or reliable analysis of them, he dealt indiscriminately with practices "of mainly medical character"such as those recorded in al-Rāzì's Sirr sinā'at al-tibb-and procedures "concerned especially with the properties of animals", that is, procedures concerning occult or superstitious virtues of animal parts that were allegedly tested. By the 1970s, on the basis of available sources at the time, actual case histories and prescriptions for real patients became overshadowed by magical and folkloric practices due to the identification of two works by the Andalusi physician Abū 1-'Alā' Zuhr (d. 525/1130)the Kitāb al-Mujarrabāt (Book on Medical Experiences) and the Kitāb al-Khawāss. (Book on Occult Properties) - as being one and the same text. ${ }^{6}$ The latter, also preserved in several manuscripts under the title Mujarrabāt al-Khawāss (Experiences of Occult Properties) and Jam' fawā' id al-muntakhaba min al-Khawāss al-mujarraba (Collection of Useful Procedures Selected from Time-Tested Occult Properties), is one of the largest compilations concerned with magical properties of animal, vegetable and mineral products. In it, the author attributed his vast collection of materials to a large number of Greco-Roman and Islamic sources. ${ }^{7}$ Its contents deal mainly with recipes such as the following:

al-Thaqāfa al-'Ilmīya, 2006), although the texts included in this article do not always coincide or appear in that printed version.

${ }^{4}$ Different in purpose, included in larger works and collected by the author himself, are the group of thirty-three case histories found in al-Rāzì's Kitāb al$H \bar{a} w \bar{w}$, and by the same author, the third chapter of his treatise entitled Sirr sina 'at al-tibb (The Secret of the Medical Art). Al-Rāzī, Kitāa al-Hāầ fì l-tibb, 23 vols, Hyderabad, Osmania Oriental Publications Bureau, 1955-68, vol. 16, pp. 189-208; Max Meyerhof, 'Thirty-three clinical observations by Rhazes', Isis, 1935, 23: 321-56 (reprinted in Studies in medieval Arabic medicine, ed. Penelope Johnstone, London, Variorum, 1984); Owsei Temkin, 'A medieval translation of Rhazes' Clinical observations', Bull. Hist. Med., 1942, 12: 102-17; Rosa Kuhne Brabant, 'El Sirr sinā'at al-tibb de Abū Bakr Muhammad b. Zakariyyā'; al-Rāzì', Al-Qantara, 1982, 3: 347-414; 1984, 5: 235-92; 1985, 6: 369-95.
For an analyisis of literary and stylistic features of these two groups of case histories, see Álvarez Millán, op. cit., note 2 above, pp. 37-41.

${ }^{5}$ Lynn Thorndike, A history of magic and experimental science during the first thirteen centuries of our era, 4th ed., 8 vols, New York, Columbia University Press, 1923-1958, vol. 2, pp. 751-74.

${ }^{6}$ Manfred Ullmann, Die Medizin im Islam, Leiden, Brill, 1970, pp. 311-13.

${ }^{7}$ For a survey of the contents of this work, see Cristina Álvarez Millán, 'El Kitāb al-Jawāss de Abū 1-'Alā' Zuhr: materiales para su estudio', Asclepio, 1994, 46: 151-74. On the sources employed for the compilation of this work, see Nikolaj Serikoff, 'Dogknights and elulargency: Greek ghost-words in medieval Arabic sources', in Claudia Sode and Sarolta A Tákacs (eds), Novum millennium: studies in Byzantine history and culture in honor of Paul Speck, Aldershot, Ashgate, 2001, pp. 357-68. 


\section{Cristina Álvarez Millán}

If you hang some hair from a dead person around an aching tooth, this will relieve the pain. ${ }^{8}$

If you wrap some flesh of a nightingale (bulbul) and the eye of a crab in a piece of stag (ayyil) leather, and hang it on somebody who wants to stay awake all night, he will not sleep as long as he wears it. ${ }^{9}$

If you want to know whether a woman is pregnant with a girl or a boy, put a louse in a person's hand and pour some of the mother's milk over it. If the louse moves away from the milk, the child is a girl and if it doesn't, it is a boy. ${ }^{10}$

As far as Islamic medical practice is concerned, this type of literature-inherited from the Greco-Roman tradition-has not to date received a thorough study, in contrast with its parallel tradition of "secrets of nature" in the Latin west. ${ }^{11}$ Perhaps this is so simply because research on medieval Islamic medicine has focused on theoretical treatises devoted to learned medicine and pharmacology, particularly those by well-known Islamic medieval medical writers. Nevertheless, in 1988, a comparison of the contents of Abū 1-'Alā' Zuhr's Kitāb al-Khawāss with a manuscript preserved at El Escorial Library purporting to contain a copy of the same work under the title Kitāb al-Mujarrabāt, revealed that the latter was concerned with prescriptions for actual patients and devoid of magical elements, that it was, in fact, truly medical, ${ }^{12}$ as the following shows:

Prescription by him [Abū 1-'Alā' Zuhr] for a man who suffered from pain and roughness in his throat and who had developed a cold. On an empty stomach he must gargle with this, that is, he must take one ounce of mulberry syrup (rubb) and half an ounce of walnut syrup, mixing it all with three and a half ounces of rose-water. He must gargle with it hot, if God pleases, be He exalted. ${ }^{13}$

In terms of medical practice, this latter type of detailed therapeutic prescription is more revealing of a physician's practice than the occasional statements found in theoretical compendia as personal verifications of the virtues attributed to a certain drug or procedure, as for instance:

Al-Shilthā: Physicians maintain that this drug [has] all [possible] beneficial properties and that its preparation includes all [sorts of] wonders, but we did not see [such] a significant effect, with the exception of $\ldots$ in tongue disorders and its laxity $\left(\right.$ istirkha $\left.\bar{a}^{\prime}\right) \ldots{ }^{14}$

\footnotetext{
${ }^{8}$ Attributed to Hermes. Abū 1-'Alā' Zuhr, Kitāb al-Khawāss, Topkapi Saray Library, Istanbul, Col. Ahmad III, MS. 2068, fol. 2a; Kitāb Mujarrabāt alKhawāss, Bodleian Library, Oxford, Oriental Collections, MS. Marsh 520, fol. 1b. All translations are mine unless otherwise indicated.

${ }^{9}$ Attributed to Kimās. Abū 1-'Alā' Zuhr, Kitāa alKhawāss, op. cit., note 8 above, fol. 12a, and Mujarrabāt al-Khawāss, op. cit., note 8 above, fol. 12a.

${ }^{10}$ Abū 1-'Alā' Zuhr, Kitāb al-Khawāss, op. cit., note 8 above, fols. 70a-b; Mujarrabāt al-Khawāss, op. cit., note 8 above, fol. $74 \mathrm{~b}$.

${ }^{11}$ See William Eamon, Science and the secrets of nature: books of secrets in medieval and early modern culture, Princeton University Press, 1994. On sympathetic therapy in medieval Islamic literature, see Manfred Ullmann, Die Natur- und

Geheimwissenschaften im Islam, Leiden, Brill, 1972,
}

pp. 393-416. For magical practices in medieval Islamic medicine, see Peter E Pormann and Emilie Savage-Smith, Medieval Islamic medicine, Edinburgh University Press, 2007, pp. 144-61; Michael W Dols, Majnūn: the madman in medieval Islamic society, ed. Diana E Immisch, Oxford, Clarendon Press, 1992,

ch. 9, 'The theory of magic in healing', pp. 261-73 (reprinted in Emilie Savage-Smith (ed.), Magic and divination in early Islam, Aldershot, Ashgate Variorum, 2004.

${ }^{12}$ Rosa Kuhne Brabant, 'Hacia una revisión de la bibliografía de Abū 1-'Alā' Zuhr (m. 1130/1)', Al-

Qantara, 1992, 13 (2): 581-5.

${ }^{13}$ Abū 1-'Alā' Zuhr, op. cit., note 3 above, pp. 125, 193.

${ }^{14}$ Ibn Sīnā, Al-Qānūn fì l-țibb, 3 vols, Beirut, s.n.,

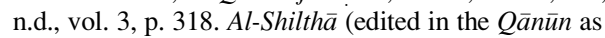
shilth $\bar{a}$, and two lines below as shatith $\bar{a}$ ) is a compound 


\section{The Case History in Medieval Islamic Medical Literature}

The treatise by Abū 1-'Alā' Zuhr preserved in the manuscript in El Escorial also contains comments on the usefulness of a given drug, critical assessments of some of Galen's remedies, discussions on physiology and pathology of certain organs, and records of pharmacological tests, either describing the invention of a new drug or modifying recipes already known in order to improve their effect. In short, the material is concerned with Abū l-'Alā' Zuhr's clinical experience. An examination of the above mentioned collections of clinical reports compiled by students of al-Rāzì and those recorded by al-Hāshimī further revealed that, in addition to prescriptions for patients, the tajärib and mujarrabāt also applied to collections of consultations which fit the category of case histories. Two examples, one from each of the two collections, follow:

A youngster complained of dizziness and pain in his knees. Then [al-Rāzī] asked: "Do you have a bitter taste in your mouth?" He replied that he did and that he had a bit of cough. [So al-Rāzī] prescribed fasting for the first day, and then a potion [made of] tablets of violet for the next two days, as well as drinking acrid pomegranate water. He said: "This illness is caused by an excess of bile that has crept to the head." Diet [to be based on] acrid substances and tifshīl. ${ }^{15}$

A man came and reported that he felt pain all over his head [accompanied by] nosebleeds and a dry, sweet taste in his mouth. He [the physician, one al-Taymī] said to him: "How is your sleep?" [The man] replied: "Heavy." [Al-Taymī] asked: "How do you feel when you get up, energetic or lazy?" [The man] said: "Lazy." The doctor said: "Cut the cephalic vein and draw ten ounces of blood, and rub your temples with caltrop (hasak) [mixed] with oil of violet and wetnurse's milk." The man was cured. I [the student] said: "Shall we take it as a norm?" [Al-Taymī] replied: "Yes, in the spring and in youth." And I asked: "[What about] diet?" He replied: "Poultry [cooked] with vinegar for the young, and vegetables (baql) and coriander (kazbürah) for the adults."

Like formal treatises on medieval Islamic medicine, medical experiences and case histories are not always free of magical, superstitious or popular elements. Nevertheless, although the line between magical and learned therapy is often a thin one, to a large extent it is possible to distinguish between collections of Khawāss and those concerning tajārib and mujarrabāt - that is, between wondrous or occult properties of particular materials, and the use of certain ingredients which were incorporated into a rational medical system such as Hippocratic-Galenic humoral medicine. The distinction between the two types of material is illustrated by Ibn Sinā's $Q \bar{a} n \bar{u} n$, the seminal textbook in European medical schools. For instance, while we find in the Q⿱ānūn that "urine is purported to be hot and dry" and the best is camel's urine, ${ }^{17}$ we would not find in it magical practices such as,

When a woman places the stone that is called "the eagle's impregnator" on her lap, giving birth is difficult for her. However, if she holds it in her hand or attaches it to her loins, she gives birth on the spot. ${ }^{18}$

remedy made of zedoary, doronicum, unbored pearls, coral, raw silk, alum, silver, gold, malabathrum, honey, pepper, saffron and musk among other simple drugs. See Martin Levey, Substitute drugs in early Arabic medicine, Stuttgart, Wissenschaftliche Verlagsgesellschaft, 1971, p. 73, n.292.

${ }^{15}$ Al-Rāzì, op. cit., note 3 above, fol. 6 a (which diverges from the corresponding printed text edited by $\mathrm{K}$ Harbī, p. 93). As for the word tifshīl, it is a dish made of leguminous vegetables such as beans and chickpeas. See Ibn al-Hashshā', Glossaire sur le Mans'uri de Razès, ed. G S Colin and H P J Renaud, Rabat, Institute des Hautes-Études Marocaines, 1941, p. 61.

${ }^{16} \mathrm{Al}-\mathrm{Ha}$ shimī, op. cit., note 3 above, pp. 21-2.

${ }^{17}$ Ibn Sinā, op. cit., note 14 above, vol. 1, p. 279.

${ }^{18}$ Gerrit Bos and Y Tzvi Langermann, 'PseudoGalen, al-Adwiya 'l-maktūma, with the commentary 


\section{Cristina Álvarez Millán}

If you cause a woman to drink from the dirt of a man's feet without knowing of it, she will never love another man besides him. ${ }^{19}$

If a deflowered woman seizes the jugular vein of a sheep, she becomes a virgin again. It is tested (mujarrab). ${ }^{20}$

Whether the therapeutic optimism conveyed in the expression mujarrab (tested) was a cliché implying authority, or just an optimistic wish on the part of the healer, the important point is that the word mujarrab never occurs in the collections of tajāib and mujarrabāt. Moreover, far from the magical character attributed to them, the medical contents of collections of medical experiences and case histories are, for the most part, linked to the purest Arabized Galenism. Nevertheless, it should be noted that the titles of the three collections of reports concerning clinical experience known to have been preserved to date were provided by the compilers, usually a disciple of the author. ${ }^{21}$ They are: Kitāb al-Tajārib (associated with al-Rāzī), Al-Majālis fi-l-tibb or "Sessions on medicine" (al-Hāshimī's collection), and Kitāb al-Mujarrabāt (Abū 1-'Alā' Zuhr's compilation). Because the sources are so few, more need to be discovered and studied in order to determine whether the use of the Arabic words tajārib and mujarrabāt were applied interchangeably by Islamic scholars (perhaps as synonyms, with one dominating in the east and the other in the west), or whether they were used to refer to different types of clinical reports. What seems apparent, however, is that the presence of those terms in the title of a medieval Islamic medical text does not necessarily mean that the contents describe medical experiences or clinical accounts as such, since many of these works-such as the Kitāb al-Khawāss under its alternative titles-are devoted to magical practices. Conversely, titles carrying the word mujarrab (tested) do not necessarily imply magical procedures of sympathetic therapy, as they may also contain learned medical knowledge. ${ }^{22}$ The same applies to works such as that by Abū 'Abd Allāh Muhammad b. Yahyá b. Ab̄̄ Tālib b. Ahmad entitled Jirāb al-Mujarrabāt (Collection of Tested Remedies), which appears to be a seventeenth- or eighteenth-century rehash of pharmacological treatments extracted from theoretical treatises by al-Rāzī, Ibn Zuhr, and others. ${ }^{23}$ In short, it is necessary to examine each work using one of these related terms in its title in order to tell what type of material it actually contains.

of Hunayn ibn Ishāq', Suhayl (Journal for the History of the Exact and Natural Sciences in Islamic Civilisation), 2006, 6: 81-112, p. 95.

${ }^{19}$ Attributed to Dioscorides. Joshua O Leibowitz and Shlomo Marcus, Sefer hanisyonot: the book of medical experiences attributed to Abraham ibn Ezra, Jerusalem, The Magnes Press, The Hebrew University, 1984, p. 255. According to Savage-Smith and Pormann (op. cit., note 11 above, pp. 148, 160), this is a Hebrew translation of the treatise on khawass by the tenth-century Andalusi author Abū al-Mutrib 'Abd al-Rahmān b. Ishāq b. al-Khaytham.

${ }^{20}$ Ibn Durayhim al-Mawsilī, Kitāb Manāfi ${ }^{\prime}$ alhayawān (Libro de las utilidades de los animales). Facsimile edition with Spanish translation by Carmen Bravo Ruiz-Villasante, 2 vols, Madrid, Kaydela and Editora Patrimonio Nacional, 1990, vol. 1, fol. 3a, vol. 2, p. 5. For a description of this manuscript, see Anna Contadini, 'The Kitāb Manāfi' al-hayawān in the Escorial Library', Islamic Art, 1988-89, 3: 33-52.

${ }^{21}$ This pattern also applies to a Hebrew-Spanish aljamiado manuscript containing a collection of prescriptions by the physician Meir Alguades (c.1350-c.1410). See, Luis García Ballester, La búsqueda de la salud: sanadores y enfermos en la España medieval, Barcelona, Península Ediciones, 2001, pp. 473-84.

${ }^{22}$ This is the case, for instance, of the fourteenthcentury work by Abū Bakr b. Muhammad al-Fārisī, Kitāb al-Durra al-muntakhaba fi l-adwiya almujarraba (Book of Selected Pearls on Tested Drugs). See Al-Khizāna al-Malakīya, Rabat, MS 2995.

${ }^{23}$ Wellcome Library, London, WMS Or. 13, and Real Academia de la Historia, Madrid, Colección 


\section{The Case History in Medieval Islamic Medical Literature}

The terms tajārib and mujarrabāt have also been linked to collections of pharmacological recipes or books on aqrāba adhīn. ${ }^{24}$ The latter were compilations of pharmacological recipes supposedly intended as guides for the prescription and manufacturing of compound medicines. In these works, remedies are usually presented according to type: syrups, pills, collyria, and so on. As for the recipes themselves entries typically report their uses, ingredients, the process of preparation and dosage. The term mujarrab (tested) frequently appears sanctioning the supposed virtues of particular compound drugs. In contrast to the aqrāba adhìn, the content of the extant collections of tajāib and mujarrabāt is arranged in a head-to-toe order. Although nosology, diagnosis, and prognosis are not always systematically given or explained in detail, the practical nature of these accounts is highlighted by the presence of pharmacological treatments with concomitant effects, such as remedies for both internal and external purposes, or a drug to purge the body and another to balance the temperament, according to the patient's particular condition. Other therapeutic methods-such as bloodletting, cupping, enemas, hydrotherapy or aromatherapy, to mention the most common ones-are occasionally employed as the sole remedy, although they usually appear as a complement to the pharmacological prescription. Additionally, virtually all case histories also incorporate a specific diet (including fasting) as part of the medical treatment. Likewise, as in the case of the al-Rāzi and al-Hāshimī examples cited above, the clinical report may also include the transcription of the interrogation of the patient or the questions and answers exchanged between the student and the physician during the consultation.

\section{Case Histories in Context}

The documentary value of clinical accounts, however, must be assessed according to the presence of literary conventions or devices, the nature of the medical work in which they appear, and the professional environment in which the physician wrote them. ${ }^{25}$ The clinical account was recorded for many different purposes. In some instances, the record of particular cases enabled a physician to establish a pattern for the usual course of a certain disease, to determine the significance of particular symptoms with regard to the final outcome, or to observe the effectiveness of a given remedy; in short, it allowed the physician to propound general medical rules. An example within the medieval Islamic medical tradition is one taken from al-Rāzì's Kitāb al-Hâầ or Continens, a voluminous book in which he recorded and commented on all the medical writings he had read and in which he included his own observations:

There was a patient who had a severe attack of a bad form of smallpox; we bled him before he felt much suffocation in his throat, and there was no cooling medicine which we did not give him. Accordingly, his throat began to be less constricted, and he was getting better from the smallpox, so that we had good hopes of his recovery. Then later, the patient was seized with a very acute pain

Gayangos, MS CLIII. Although unreliable as an edition and wrongly attributed to al-Rāzī, see the Arabic text published by Khālid Harbī, Jirāb al-

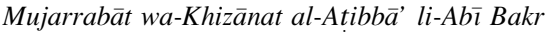
Muhammad b. Zakarīyā' al-Rà̄z $\bar{\imath}$, Alexandria, Dār alThaqāfa al-'Ilmīya, 2006.

\footnotetext{
${ }^{24}$ See B Lewin, 'Akrābadhīn', Encyclopaedia of Islam, op. cit., note 1 above, vol. 1 , pp. 354-5.

${ }^{25}$ For an analysis of the clinical account in the Greco-Roman period and the progressive shift of features and focus, see Álvarez Millán, op. cit., note 2 above.
} 


\section{Cristina Álvarez Millán}

in his leg, and the blisters turned black, and he died of the violence of the pain that same day. I had intended to scarify that part of his leg, but his strength began to sink within an hour, so that I had no hope of saving him, and at last he fell into such a state that blood began to flow from the pores of his skin. [The clinical account ends with the final general observation:] I have seen several patients in whom large blisters of a certain type came out, and who had, towards the end of the disease, a pain in the leg. ${ }^{26}$

Case histories can also be the product of medical teaching, which in turn allows clinical experience to be shared with other physicians and potential practitioners. As a didactic tool, case histories were particularly relevant for a student's medical training because they provided practical knowledge acquired only by experience. Take, for instance, the following example from the Kitāb al-Tajārib or Casebook recorded by al-Rāzī's students:

For a person whose urine was black, resembling that of someone suffering from jaundice caused by black bile, he [al-Rāzī] prescribed the regular intake of chicory water (or absinth water in the event of chicory not being available) with oxymel. We [the students?] said: "Is [an infusion of] black nightshade ('inab al-tha 'lab) to be recommended?" He [al-Rāzī] said: "No, because it purges the bowels and [because] the chicory water causes stools to be white like [those induced with] white figs; when stools are dyed and their colour increases, the colour of the urine decreases" [that is, the colour of urine would be misleading for diagnostic purposes]. He [al-Rāzī] also prescribed cassia (khiyārshanbar) and syrup of violets for [the patient] in order to stimulate his peristaltic movement and [when stools came out] they were like the white fig, as he said they would be. ${ }^{27}$

Interestingly, both of these compilations of al-Rāzì's clinical experience are an unusual form of medical treatise in that they were not intended for publication during his lifetime: the Kitāb al-Hâa $\bar{\imath}$ is a collection of notes for his private use assembled for circulation by his students only after his death, and the Kitäb al-Tajärib is a record of cases treated by him or his students under his supervision and recorded by his pupils. Linked as they are to medical self-instruction and teaching respectively, al-Rāzì 's personal testimonies and medical accounts contain little-if any-literary adornment. More importantly, they appear to be a literal and reliable source as far as the depiction of medical practice and training is concerned.

A similar status applies to two other works: first, the medical experiences inserted in the Book on medicine by al-Kashkarī (fl. first half of tenth-century $\mathrm{AD}$ ), whose contents are linked to the author's medical practice in the hospitals of Baghdad and which "resembles more an ill-digested aide-mémoire than a well organised encyclopaedia", possibly because it was destined primarily for readers within the author's circle. ${ }^{28}$ Second, the collection of clinical accounts compiled by Ahmad b. 'Īsá al-Hāshimī, a medical student in eleventh-century al-Andalus, since consultations were actually carried out under the supervision of the teachers he studied with. An example of the latter,

${ }^{26}$ Al-Rāzì, Kitāb al-Hāầi, op. cit., note 4 above, vol. 17, p. 25; translation by William A Greenhill, A treatise on the small-pox and measles, London, Sydenham Society, 1848, pp. 120-1, slightly amended.

${ }^{27}$ Al-Rāzī, op. cit., note 3 above, fol. $72 b$ (missing in K Harbī's edition).

\footnotetext{
${ }^{28}$ See Peter E Pormann, 'Theory and practice in the early hospitals in Baghdad. Al-Kaškarī on rabies and melancholy', Zeitschrift für Geschichte der Arabisch-Islamischen Wissenschaften, 2002-2003, 15: 197-248, pp. 197, 227 (examples on pp. 246-7, \$17-18).
} 


\section{The Case History in Medieval Islamic Medical Literature}

concerned with the scission of a haemorrhoid performed by 'Abd Allāh b. Muhammad b. Hazm b. Harb al-Taymī (d. after 470/1077), ${ }^{29}$ illustrates aspects such as bedside manners and how to deal with the patient's fear:

A man came and stated that he had a wart $\left(t h u^{\prime} l \bar{u} l\right)$ in his anus like a small and hard acorn, which had not bled, except in the spring, [when] it became soft and would bleed if his clothes or his hand touched it. At other seasons, it did not bleed. [Al-Taymī] instructed me to look at it. So I made the man display [it], and there it was hanging, nearly black. Then [Al-Taymī] said to me: "How is it in relation to the exit? Is it towards the inside or the outside?" I said: "It is towards the outside." [AlTaymī] said to the patient: "There is no option for you but to excise it and apply a cautery." The man was alarmed and said: "I wish something milder." [Al-Taymī] said: "There is no [other] option." So the man said: "Cut it!" [So al-Taymī] took a pair of long and plain scissors like those with which loose threads [of rugs] are cut at Chinchilla, ${ }^{30}$ then he heated the tips and excised [the wart] with the heated scissors. And so it was cut and cauterized [at the same time]. On the affected area, [Al-Taymī] applied flesh of goat's kidney with extract of roasted almond, and so he exhausted him. After that, I cut it with a scalpel and cauterized it, the cautery following the cutting, and the man was cured. ${ }^{31}$

In the case of al-Hāshimī's collection of clinical accounts, it is not clear whether he compiled them at the time of his training as material for study-and perhaps, for future reference - or later in life for some other purpose. Whether it is a step by step literal transcription of the ongoing consultation, or a later reconstruction, the author presents himself as a student assisting his master and the resulting description of events lacks any literary sophistication.

The narrative style of some case histories included in theoretical treatises is, however, very different. The incidence of clinical records to be found in medieval Islamic learned monographs and compendia is proportionally scarce. Moreover, as Dimitri Gutas puts it, "[D]escription of practices as supporting theory, including specific case histories, was the exception and not the rule." ${ }^{32}$ Statements concerning the successful application of a given pharmacological potion for a particular ailment are likely to be encountered much more often than a detailed description of the corresponding medical consultation at the patient's bedside. However, not all Islamic physicians restricted themselves to aseptic medical theorizing, some indulged in personal comments that reflect the writer's own experiences. We shall now focus on this latter type of medical text-as well as on the type of case histories they convey-in order to contrast it with those seen so far in this paper. The two clinical accounts selected as examples were ostensibly included by the author to support a theoretical discussion, although the first is also supposed to

\footnotetext{
${ }^{29}$ See Ibn Bashkwāl, Kitāb al-Sila, ed. F Codera, 2 vols, Madrid, imprenta José de Rojas, 1882-1883, vol. 1, p. 217, biography 615 .

${ }^{30}$ I wish to thank Prof. Federico Corriente and Dr Joaquín Bustamante for their assistance in the interpretation of the Arabic word "jinjallah". The first considered the term to be the Arabized Latin word from which the Spanish term "cizalla" (wire cutters) is derived, and the second interpreted it as the Arabic name for the Spanish town Chinchilla (Albacete), an important rug manufacturing centre in medieval
}

Spain. Despite the lexical discrepancy, the point is that the student compares the scissors used by alTaymī with those employed by rug weavers to finish off their work.

${ }^{31}$ Al-Hāshimī, op. cit., note 3 above, p. 84.

${ }^{32}$ Dimitri Gutas, 'Medical theory and scientific method in the age of Avicenna', in David C Reisman (ed.), Before and after Avicenna. Proceedings of the First Conference of the Avicenna Study Group, Leiden and Boston, Brill, 2003, pp. 145-62, on p. 157. 


\section{Cristina Álvarez Millán}

warn against getting personally involved in fatal cases. In both accounts, however, another element shows up, namely, tacit or even explicit criticism of incompetent colleagues, thus highlighting the author's own skill, ethics or bedside manners. The first example is taken from the surgical treatise Kitāb al-Istiqșa $\bar{a}$ ' wa-l-ibrām fì 'ilāj al-jirāhāt wa-lawrām (Book of the Investigation and Confirmation on the Treatment of Wounds and Tumours) by the Andalusi physician and surgeon Abū 'Abd Allāh Muhammad b. 'Al̄̄ b. Farāj al-Qirbilyān̄̄ (d. 761/1360), known as al-Shafra (literally meaning "the Razor"): ${ }^{33}$

Boils (damāmìl): They are a type of inflamed (falghumūnì) swelling — as we said earlier-which is formed from thick and corrupted blood. When they occur, it is important not to overlook their treatment, since sometimes all the diseased matter combines in one place and consequently, it becomes one large swelling, which is difficult to cure, and sometimes it even results in death. I myself have seen a woman of the Banu Abi al-'Ulá on whom four of the boils erupted on the right side of [her] head, [in a place] where she had much hair. One of the boils was on the temple, another one was in front of the ear, another was behind it, and another was close to the nape of her neck. Afterwards, they combined and it became one swelling. When I saw it, the purulent matter had begun to appear in the boil located on her temple. I did not intervene in her treatment, as a cupper had visited her. It happened in Ceuta. When the boil was mature, he [the cupper] opened it and the pus which had been maturing inside came out, and there appeared some white vessels [which looked] like roots. [The cupper] opened another boil, the one located in front of her ear. Later on, he opened [the boil] close to the nape of her neck, ten days elapsing between each opening. Then a blackness appeared in the boil which was close to the nape of the neck, and fever set in. I informed them [the family?] that it was a sign of concern and that a person in that state seldom survived. It was apparent to her family that what had happened was due to the cupper's little knowledge. So, they summoned the physician Sulaymān al-Muhājir, who visited the woman in the cupper's company, and he [the physician] cut away the corrupted flesh, but about seven days later, she died, God have mercy on her. ${ }^{34}$

Regarding the literary context, Muhammad al-Shafra's personal testimony belongs to a treatise dedicated to his son, but we should not be misled by what appears to be a literary topos disguising less altruistic purposes than guiding his heir's first steps in medical practice. In fact, as far as is known, there is no evidence that al-Shafra's son ever practised surgery, and no biographical dictionary appears to have noted his existence. Moreover, al-Shafra's clinical account conveys features of a literary nature evident in his role as a mere observer of the patient's fatal progress, and in the reference to a cupper with "little medical knowledge" and no formal medical training at all. Additionally, the patient eventually dies under the medical care of a colleague. According to al-Shafra's initial statement, the condition under discussion is not necessarily lethal, and he presents himself as an experienced physician since he is able to discern a sign of concern and to predict the final outcome. Also, throughout his surgical work, al-Shafra often refers to

\footnotetext{
${ }^{33}$ For a description of his life and his surgical treatise, see Eloísa Llavero Ruiz, 'La medicina granadina del siglo XIV y Muhammad alŠafra', Revista del Centro de Estudios Históricos de Granada y su Reino, new series, 1992 . 6: $129-50$.
}

\footnotetext{
${ }^{34}$ Abū 'Abd Allāh Muhammad b. 'Alī b. Faraŷ alQirbilyān̄̄, conocido por al-Ŝafra, Kitāb al-Istiqșă, (Libro de la indagación exhaustiva), ed. with Spanish transl. by Eloísa Llavero Ruiz, 3 vols, Alicante, Instituto Alicantino de Cultura Juan Gil-Albert, 2005, vol. 2, pp. 123-4, and vol. 3, p. 27.
} 


\section{The Case History in Medieval Islamic Medical Literature}

the lack of skilful physicians and surgeons in his lifetime-a claim which is to be found frequently in medieval Islamic medical writings. Seen from this perspective, one must wonder what his role was in this particular consultation, and why he did not intervene at all to save the patient.

A different attitude can be found in the second clinical account, included in a theoretical medical text by Ibn Zuhr (d. 557/1162), known in the Latin tradition as Avenzoar. ${ }^{35}$ It appears in his work Kitāb al-Iqtisād fi islāh al-anfus wa-l-ajsād (Book of Moderation Regarding the Restoration of Souls and Bodies), also known as Kitāb al-Zīna (Book on Cosmetic Medicine): ${ }^{36}$

I certainly have the habit of strengthening astringent drugs (adwiyah muqabbidah) with [other] substances which are of a viscous and sticky nature while being cool, like the fleawort (bizrqatunā). With regard to this, I know a case which happened at the beginning of my career, a bit after I began medical practice. At the time, I was summoned to visit a man from Cordoba, who was a foreigner amongst us. A huge nosebleed had set in and had wasted his strength, and the best known [physician] from the city had given up the case. When I came to him, I saw that he was a young man of average build (wa-jismu-hu wasittan), not very thin nor fat, and I had the impression that perhaps he was keen on wine. It crossed my mind that he was affected by an excessive humoral heat, and I inquired whether he had taken any heating drug. He replied that he had. I said: "Did the heat of the sun, the effort and the fatigue of travel worsen your state?" He nodded. I asked him in front of some of them what the [other] doctors had done, and I realized that they had already taken a decision [regarding the diagnosis] and had begun to apply treatment. So I took the same drugs, increasing the amount of each ingredient by one part, [adding] the maximum dose of crushed fleawort and a small amount of camphor. Additionally, I replaced half the water he used to drink with watermelon $\left(\right.$ dalla $\left.^{\natural}\right)$ juice, and added another drug which the people [the physicians in charge of the patient] had omitted. I instructed his head to be shaved and iced water poured constantly over it, so that [the ice] would melt on it. The nosebleed stopped, decreasing little by little. I have only mentioned this episode to you so that it serves you as example and norm. ${ }^{37}$

Ibn Zuhr became involved in a difficult case a little after he began to practise, and, although he was still a very young doctor, he was summoned because the best physicians of the city were unable to restore the patient's health. However, stylistic conventions-such as allusions to the patient's fondness for wine, famous physicians having

\footnotetext{
${ }^{35}$ For his biography, see Cristina Álvarez Millán, 'Ibn Zuhr', in Thomas F Glick, Steven J Livesey and Faith Wallis (eds), Medieval science, technology and medicine: an encyclopaedia, London and New York, Routledge, 2005, pp. 259-61. For a full biography, description of the contents of his works, extant manuscripts and bibliography, see Rosa Kuhne Brabant and Cristina Álvarez Millán, 'Abū Marwān 'Abd al-Malik b. Zuhr', in Jorge Lirola (ed.), Biblioteca de al-Andalus, 7 vols, Almería, Fundación Ibn Tufayl, 2004- (vols 1 and 7, forthcoming), vol. 6, pp. 352-68.

${ }^{36}$ See the following by Rosa Kuhne Brabant: El Kitāb al-Iqtisād de Avenzoar según el ms. $n^{\circ} 834$ de la Biblioteca del Real Monasterio de San Lorenzo de El Escorial (extracto de tesis doctoral), Madrid,
}

Facultad de Filosofía y Letras, 1971; 'Avenzoar y la cosmética', in J M Barral (ed.), Orientalia hispanica: sive studia F. M. Pareja octogenario dicata, Leiden, Brill, 1974, pp. 428-37; 'Zìna e Islāh. Reflexiones para entender la medicina estética del joven Abū Marwān b. Zuhr', Al-Andalus-Magreb, 1996, 4: 281-98

${ }^{37}$ Abū Marwān 'Abd al-Malik b. Zuhr, Kitāb alIqtisād fi islāh al-anfus wa-l-ajsād, Real Biblioteca del Monasterio, El Escorial, MS 834, fols 33a-33b. I owe a debt of gratitude to the late Dr Kuhne Brabant for her permission to include that source in this paper, as well as for providing me with her edition of the Arabic text and Spanish translation, which will be published posthumously. 


\section{Cristina Álvarez Millán}

given up the case, Ibn Zuhr's quick clinical eye at an early stage of his career, and his taking up the star role in the story by means of talking in the first person-reveal a strong Galenic influence on the writing up of this particular report. ${ }^{38}$ This form of clinical account is set in a work dealing with cosmetic treatments which Ibn Zuhr wrote in 515/1121 for his protector, Ibrāhīm b. Yūsuf b. Tashufīn, a member of the Almoravid dynasty and governor of Seville at the time. Written in his youth-and one of his first literary efforts-Ibn Zuhr attributes to himself a pioneering role with that treatise, implying that only Criton and Cleopatra had dealt with the same subject before him. He omits any reference to earlier Islamic sources throughout the work, particularly ignoring Abu 1Qāsim al-Zahrāwī (d. c.400/1009), a major Andalusi physician, who had actually written on cosmetics before him. It is true, however, that along with the traditional cosmetic treatments to improve hair, nails or the skin, Ibn Zuhr goes beyond his predecessors, propounding surgical methods for hideous noses, inadequate lips, ugly ears, or congenital malformations. The author's claims and innovative approach, however, echo every Galenic convention for self-advertisement, particularly if we bear in mind that the mere sight of blood virtually caused Ibn Zuhr to vomit and even faint, as he himself admitted in a later work. ${ }^{39}$ In this context, even if the case history above reflects the application of the humoral medical system in the form of cooling agents to counteract a hot imbalance, its objective is, none the less, to convince a given audience of his medical talent.

All clinical accounts included in the treatises by Muhammad al-Shafra and Abu Marwān b. Zuhr follow the same pattern, and may well be representative of the general tone of case histories included in medieval Islamic theoretical works. It is also useful

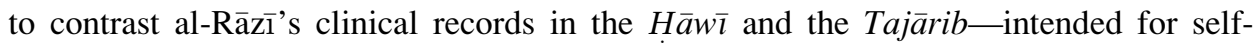
instruction and teaching-with those he included in the Sirr sina'at al-tibb (The Secret of the Medical Art), a medical work of a theoretical nature. In this short treatise devoted to popularizing medicine, al-Rāzī displayed many elements of Galen's theatrical rhetoric. ${ }^{40}$ It is apparent that medieval Islamic physicians were aware of Galen's persuasive strategies for self-promotion and the construction of an authoritative voice, including the production of dramatic clinical accounts highlighting his superiority, which, rather than throwing light on the workings of medical practice, entertained the reader. It should be remembered that medieval Islamic physicians shared with Greco-Roman physicians the need for case histories to publicize their medical skill.

A quick look at the history of medieval Islamic medicine shows that virtually all theoretical treatises-particularly those which had a major impact on the western medical tradition-were written by medical authors working for governors or princes. In other words, while rulers undertook intellectual and artistic patronage to help extend their

\footnotetext{
${ }^{38}$ For comparison, see Galen's collection of major cases, On prognosis, ed., transl. and commentary by Vivian Nutton, Berlin, 1979 (Corpus Medicorum Graecorum, V 8.1). See also, 'Galen and medical autobiography', in Vivian Nutton, From Democedes to Harvey: studies in the history of medicine from the Greeks to the Renaissance, London, Variorum Reprints, 1988, pp. 50-62.
}

\footnotetext{
${ }^{39} \mathrm{Ibn}$ Zuhr, Kitāb al-Tays̄̄r fi mudāwāt wa-ltadbīr, ed. G Khoury, Damascus, 1983, p. 70: "Fainn̄̄ matā ra'aytu al-jirāhāt da 'ifat nafsī hattā akāda an yaghshá 'alayya wa-lā ra'aytu qitt māddah illā watahawwa'at ma'idatī wa-rubbama taqayya'tu”.

${ }^{40}$ Kuhne Brabant, op. cit., note 4 above. See also Álvarez Millán, op. cit., note 2 above, pp. 40-1.
} 


\section{The Case History in Medieval Islamic Medical Literature}

hegemony and the cultural influence of their courts, on the authors' side there was a practical concern not only for medical scholarship, but also for making one's name known in political and social circles as much as in the professional sphere. A significant example is the vitriolic dispute in writing between Ibn Butlān (d. after 455/1063) and Ibn Ridwān (d. 460/1067-8), for a long time considered an outstanding medico-philosophical text. The core of their exchange consisted of ten essays regarding whether or not the chicken is of a warmer nature than the chick. The rhetorical nature of the argument and their mutual attacks have been shown to have been motivated by Ibn Butlān's need to become publicly known in a new city in which he wished to promote himself, and by Ibn Ridwān's need to prevent his reputation and position from being threatened, or shared, by a foreign newcomer. ${ }^{41}$ A mastery of Greco-Roman medical works was essential for Islamic physicians who wished to acquire a reputation for learning as well as to gain access to the professional or political elite, and, therefore, the controversy illustrates the physician's need to show a profound knowledge of his classical predecessors just as much as his desire to surpass contemporary competitors.

Similarly, it should be noted that criticism served as an additional and effective selfmarketing strategy in medieval Islam. There is, for instance, the case of Ibn Zuhr's father, Abū l-'Alā' Zuhr. He enjoyed a powerful political position, particularly in the Sevillian court, and it does not seem coincidental that-aside from the impressive list of Greco-Roman sources displayed in his Kitāb al-Khawāss-all his medical works consisted in refuting, expanding or improving earlier medical treatises by the most authoritative Oriental colleagues (namely Ibn Masāwayh, al-Kindī, al-Rāzī, Ibn Sīnā, and Ibn Ridwān) ${ }^{42}$ Furthermore, since the details of learned medical theory seem to have been substantially neglected in actual practice, it appears that the production of learned medical "best-sellers" was part of the game of asserting authority in the public sphere so as to maintain social prestige and gain patronage. In this context, it is reasonable to question whether clinical accounts in these compendia intended for publication always reflect the way in which a learned physician applied medical theory to practice. On the basis of the reports cited above, the answer is that case histories are not always a reliable source for determining actual medical practice.

A critical approach is particularly necessary when dealing with another category of case histories. Clinical accounts not only appear in theoretical treatises, but have also found their way into non-medical sources, particularly into the Islamic literary genre of biographical dictionaries. Medical anecdotes and supposed "real cases" included in this type of work have often been the basis for enthusiastic, but uncritical, praise of medieval Islamic physicians. However, they essentially belong to the story-telling genre. Recent research has challenged their value as documentary evidence, stressing the need to interpret the accounts they convey in the context of the whole work and the author's purpose, which might range from historical instruction, public entertainment,

\footnotetext{
${ }^{41}$ See Lawrence I Conrad, 'Scholarship and social context: a medical case from the eleventh-century Near-East', in Don Bates (ed.), Knowledge and the scholarly medical traditions, Cambridge University Press, 1995, pp. 84-100.
}

\footnotetext{
${ }^{42}$ For a comprehensive biography, description of the contents of his works, extant manuscripts and bibliography, see Cristina Álvarez Millán, 'Abū 1-'Alā' Zuhr', Biblioteca de al-Andalus, op. cit., note 35 above, vol. 6 , pp. 340-50.
} 


\section{Cristina Álvarez Millán}

social moralizing and political propaganda, to self-aggrandizement. ${ }^{43}$ From a modern perspective, some of these anecdotes seem to be aimed at maintaining the collective memory of a cultural icon or a glorious past, while at the same time instructing and entertaining.

Take, for instance, the account by Ibn Abī Usaybi ‘a (d. 668/1270), a physician work-

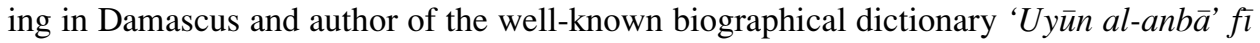
tabaqāt al-atibbā' (Sources of Information Concerning the Generations of Physicians). The story involves the Almohad ruler 'Abd al-Mu'min — who had taken over the government of Seville in 542/1147—and Ibn Zuhr. By then, the famous Andalusi physician had experienced a painful period of persecutions by the former Almoravid dynasty, which eventually ended in his imprisonment at Marrakesh. When the Almohad dynasty took over political power, Ibn Zuhr soon gained the protection of the new ruler, to whom he dedicated his most renowned treatises: the Kitāb al-Taysī fì mudāwāt wa-l-tadbīr (Book to Facilitate Therapeutics and Regimen) and the Kitāb al-Aghdhiya (Book on Dietetics). Ibn Abī Usaybi'a reports the following:

I was told by Abū al-Qāsim al-Mu'ājīnī al-Andalusī that the caliph 'Abd al-Mu'mīn needed to take a purgative drug. He hated having to drink purgative potions, so Ibn Zuhr made it easy for him. He went to a vineyard which was in his ['Abd al-Mu'mīn's] garden. He replaced the water to irrigate the vineyard with water to which he had transmitted the properties of the purgative drug, either by means of soaking or decoction. When the vineyard had absorbed the properties of the purgative drug that he wanted and grapes were formed containing those properties, he forbade the caliph to eat them. Then Ibn Zuhr went to him with a bunch of these grapes and asked him to eat them, which he did since he trusted Ibn Zuhr. The caliph began to eat the grapes, until Ibn Zuhrwho was looking at him—said: "That is enough, oh Prince of Believers, for you have taken ten grapes, and they will cause you to defecate ten times." The caliph asked why, and he was informed. Afterwards, he defecated as many times as Ibn Zuhr had mentioned, finding relief, [so that the caliph] approved of Ibn Zuhr's method and increased his esteem for him. ${ }^{44}$

Ibn Zuhr is one of the few medieval Islamic physicians who included a number of case histories in his writings, although this account by Ibn Abī Usaybi'a does not seem to have been preserved in any of his works. One may perhaps assume that the nature of the therapy was too delicate a matter to be recorded by Ibn Zuhr himself in a book addressed to the patient in the story, that is, his protector. Nevertheless, it is relevant to note that the account reached Ibn Abī Ușaybi'a by word of mouth more than a century after Ibn Zuhr's death, and therefore, it could have been subject to refinement, adornment, or more likely, to simple invention given the time required to grow such grapes when the ruler's treatment needed to be administered urgently. Whether the account reflects Ibn Zuhr's actual skill for innovative therapy or was elaborated after his death, it undoubtedly bears witness to the medieval Islamic fondness for success stories and clever strategies.

\footnotetext{
${ }^{43}$ See Cristina Álvarez Millán, 'Medical anecdotes in Ibn Juljul's biographical dictionary', Suhayl (Journal for the History of the Exact and Natural Sciences in Islamic Civilization), 2004, 4: $141-58$.
}

\footnotetext{
${ }^{44}$ Ibn Abī Ușaybi ‘a, 'Uyūn al-anbā' fì tabaqāt alatibba $\bar{a}$, ed. Gustav Müller, 2 vols, Cairo, Bulāq, 1882 (reprint F Sezgin, Frankfurt am Main, Institute for the History of Arabic Islamic Science at the Johann Wolfgang Goethe University, 1995), vol. 2, p. 66.
} 


\section{The Case History in Medieval Islamic Medical Literature}

\section{The Forging of a Myth: Ibn Sīnā's Case Histories}

Until recently, theoretical treatises have conditioned our admiration for medieval Islamic physicians as actual practitioners. However, the latest research has begun to suggest a more complex story. The purpose of this section is to begin to assess the clinical accounts attributed to the most renowned Islamic physician, Ibn Sīnā (d. 428/1037). ${ }^{45}$ Known in Europe as Avicenna, for many modern scholars he occupies the highest position in Islamic medical history, as does his major medical work, al-Qānūn fi l-țibb (Canon of Medicine). This massive medical encyclopaedia became the most authoritative stock of medical information, both as a textbook for students of medicine and as a vade-mecum for medical practitioners. Both in the east and the west, the Qānūn not only made available an extensive systematization of medical knowledge, but also synthesized the dispersed and fragmentary medical literature existing at the time, mainly Galenic treatises blended with Aristotelian natural philosophy. ${ }^{46}$ Translated into Latin by Gerard of Cremona in the twelfth century, and again by Andrea Alpago in 1527, the $Q \bar{a} n \bar{u} n$ was the most influential Arabic medical text in European universities, where it was used as a textbook until the eighteenth century. ${ }^{47}$

Ibn Sinā's book embraced all the theoretical principles of the medical profession and determined, to a large extent, the development of medical teaching in Europe. But what do Ibn Sin̄ā's case histories tell us about him as a practising physician? Are there in fact any detailed case histories that can unequivocally be assigned to him? More particularly, the $Q \bar{a} n \bar{u} n$ appears to lack detailed descriptions of personal experiences and observations, such as those by al-Rāzī regarding smallpox. Likewise, no illustrative examples, either for didactic purposes or for entertainment, are to be found in it, though there are brief statements of his preference for one remedy over another and a few comments questioning or praising the effects of certain treatments.

The most detailed accounts of Ibn Sinā's clinical experience are found in his autobiography, completed after his death by his student al-Juzjān̄̄. ${ }^{48}$ This work not only gives a precise account of how easily he came to master all possible sciences in record timeparticularly medicine, the "easiest" of all—but also tells us about the times he fell into

\footnotetext{
${ }^{45}$ See Ullmann, op. cit., note 6 above, pp. 152-6; M Mahdi, et. al., 'Avicenna', in Ehsan Yarshater (ed.), Encyclopaedia Iranica, 8 vols, London and New York, Routledge \& Kegan Paul, 1985-[1998], vol. 3, pp. 66-110; A M Goichon, 'Ibn Sīnā', in Encyclopaedia of Islam, op. cit., note 1 above, vol. 3, pp. 965-72; Floréal Sanagustin, 'Ibn Sīnā, ou la raison médicale maitrisée', Medicina nei Secoli, 1994, 6: 393-406.

${ }^{46}$ For a description of the structure of the contents, see Emilie Savage-Smith, 'Medicine', in Roshdi Rashed (ed.), Encyclopedia of the history of Arabic science, 3 vols, London and New York, Routledge, 1996, vol. 3, pp. 921-2; and B Musallam, 'Avicenna, X: biology and medicine', Encyclopaedia Iranica, op. cit., note 45 above, vol. 3, pp. 94-9.

${ }^{47}$ See Danielle Jacquart and Françoise Micheau, La médecine arabe et l'Occident médiéval, Paris, Maisonneuve et Larose, 1990; Nancy Siraisi,
}

Avicenna in Renaissance Italy: the Canon and medical teaching in Italian universities after 1500, Princeton University Press, 1987; Emilie SavageSmith, 'Europe and Islam', in Irvine Loudon (ed.), Western medicine: an illustrated history, Oxford University Press, 1997, pp. 40-53, on p. 45.

${ }^{48}$ Ibn Abī Usaybi 'a, op. cit., note 44 above, vol. 2, pp. 2-20. The text has been edited and translated into English by William E Gohlman, The life of Ibn Sina : a critical edition and annotated translation, Albany, NY, State University of New York Press, 1974. See also the thorough analysis of Avicenna's autobiography by Dimitri Gutas, 'Avicenna, II: biography', Encyclopaedia Iranica, op. cit., note 45 above, vol. 3, pp. 67-70, and idem, Avicenna and the Aristotelian tradition: introduction to reading Avicenna's philosophical works, Leiden, Brill, 1988, pp. 22-30, 194-98. 


\section{Cristina Álvarez Millán}

disgrace and then regained his reputation. Yet, few references are made to his actual medical practice. When a patient is mentioned, little or no information is given regarding the nature of the condition, its treatment and subsequent course. For instance, he mentions that the Sultan Nūh ibn Mansūr "had an illness which baffled the doctors. Since my name had become well known among them as a result of my zeal for learning and reading, they brought me to his attention and asked him to summon me. Thus I presented myself and joined with them in treating him, and so became enrolled in his service." 49 Immediately afterwards, he was given access to the Sultan's library which contained books "whose names had not reached very many people and which I had not seen before that time, nor have I seen since". ${ }^{50}$ Medical details of the Sultan's condition are omitted at the expense of Ibn Sīnā's own biographical facts. This passage, like many others in his autobiography, is not concerned with his medical practice at all, but is aimed at describing his autodidactic learning, his privileged knowledge and increasing prestige. It is worth noting that, according to Ibn Sinā's own words, he entered the Sultan's service on account of his zeal for study, not because of his reputation, or his experience as a physician.

Later on, Ibn Sīnā worked in the service of the Emir Shams al-Dawla, who had summoned him to cure his recurrent colics. In the course of a military campaign, the Emir's illness became more severe and he eventually died as a result of this and "other ailments which his not taking care of himself and seldom accepting the Master's orders caused". 51 Again, no information is given about the patient's health complications, although Ibn Sinā's student did not fail to blame the patient for his own death.

Al-Juzjān̄̄ also stated that Ibn Sinnā carried out many consultations (tajārib) which he intended to record in the $Q \bar{a} n \bar{u} n$, although the quires in which he had jotted down his medical experience were lost before the completion of that treatise. ${ }^{52}$ Leaving aside the fact that Ibn Sinnā's supposed intention might have been inspired by al-Rāzī, ${ }^{53}$ it is worth noting that the medical anecdote given by way of example immediately after that statement involves a simple case of self-healing. Being himself affected by a headache, and fearing that a swelling would develop in the membrane of his skull, he wrapped a large supply of ice in a cloth and covered his head with it, and thus was cured. ${ }^{54}$ What is significant is the fact that a look at his exhaustive compendium shows that the treatment applied to himself is not recorded amongst the large number of those that Ibn Sīna advocates in the long section in the $Q \bar{a} n \bar{u} n$ devoted to headaches. ${ }^{55}$ This is

${ }^{49}$ Gohlman, op. cit., note 48 above, p. 35 .

${ }^{50}$ Ibid., p. 37.

${ }^{51}$ Ibid., p. 57.

${ }^{52}$ Ibid., p. 73-75

${ }^{53}$ For a discussion of Ibn Sīnā's originality, see Albert Z Iskandar, A catalogue of Arabic manuscripts on medicine and science in the Wellcome Historical Medical Library, London, Wellcome Historical Medical Library, 1967, pp. 29-32. See also Martin Plessner, 'The natural sciences and medicine', in Joseph Schacht and C E Bosworth (eds), The legacy of Islam, Oxford, Clarendon Press, 1974, p. 449; and Irene Fellmann, 'Ist der Qānūn des Ibn Sīnā ein
Plagiat des K. al-Hāwī̄ von ar-Rāzì?', Zeitschrift für Geschichte der Arabisch-Islamischen Wissenschaften, 1984, 1: 148-54.

${ }^{54}$ Gohlman, op. cit., note 48 above, p. 75.

${ }^{55}$ Ibn Sinā, op. cit., note 14 above, vol. 2, pp. 31-42. Ibn Sīnā describes twenty types of headache and their corresponding therapies, consisting of simple drugs, such as cooling or warming agents, dressings, plasters, compound medicines, diet, sleep, bloodletting and various means of evacuation, steam-bath, aromatherapy, etc., according to the headache's nature or cause. 


\section{The Case History in Medieval Islamic Medical Literature}

another instance in which practice appears to have differed from theory and to have consisted of the simplest possible methods using readily available substances.

The account of his self-treatment shares a feature in common with other accounts of Ibn Sīnā's practice - that is, there is no mention of the humoral suitability of the treatment. This is also the case with the following clinical account reported in his biography. It concerns a woman affected by a withering condition ( sill) whose symptoms included what we would today identify as pulmonary tuberculosis. Ibn Sīnā ordered no medicine for her other than rose-honey (julanjubīn) made with sugar, until, in the course of time, she had taken one hundred mann of it, and was cured. Incidentally, one mann is approximately equivalent to $454.3 \mathrm{grs} ;{ }^{56}$ the woman's total intake, therefore, would have been around forty-five kilograms of rose-honey made with sugar. ${ }^{57}$

Perhaps the most significant medical examples concern Ibn Sinā himself, for there was another attempt, woefully unsuccessful, at self-healing. His student informs us of his master's sexual appetite, which was "the most vigorous and dominant of his concupiscible faculties, and he exercised it often". ${ }^{58}$ As a consequence, Ibn Sīnā was seized by colic, ${ }^{59}$ at a time when he was involved in a retreat from a military siege, and needed to recover at once so as not to delay the march. Consequently, "he administered an enema to himself eight times in one day, to the point that some of his intestines ulcerated and an abrasion broke out on him". ${ }^{60}$ The account of Ibn Sinnā's unfortunate self-treatment is softened by diverting attention to a colleague, who, whether intentionally or by mistake, added a larger amount of a certain drug than required over the subsequent therapeutic sessions, thus aggravating the ulceration. Ibn Sinā is also presented as the target of attempted murder by one of his slaves, who threw a large quantity of opium into the theriac which Ibn Sinā was also administering to himself. Nevertheless, the biography goes on to tell us that "he continued to treat himself until he was able to walk. He attended the court of 'Alā' al-Dawla, and in addition to that he did not take care and frequently had sexual intercourse", so that he had intermittent relapses until he eventually passed away a few days later. ${ }^{61}$

This is as close as we can get to details of Ibn Sinnā's medical practice. Aside from the three accounts given above, our knowledge of his clinical experience is limited to some later entertaining medical anecdotes. The most famous clinical account attributed to him is the one concerning a case of love-sickness. It was recorded by Nizāmī-i 'Arūdīi $-\mathrm{i}$ Samarqandī (fl. first half of twelfth century) in his Chahār maqālah, a Persian book of $a d a b$ - a genre of literature specifically concerned with the manners and ethics of society, written as much to entertain as to enlighten its readers. According to the source, the young physician Ibn Sinna was summoned to the bedside of the patient, a relative of

\footnotetext{
${ }^{56}$ Walther Hinz, Islamische Masse und Gewichte Umgerechnet ins metrische System, Leiden, Brill, 1955, pp. 16-23.

${ }^{57}$ It is no wonder that Ibn Sinnā was reluctant to mention the quantity of this preparation that the woman consumed when he proudly reported this treatment in his $Q \bar{a} n \bar{u} n$. Ibn Sīnā, op. cit., note 14 above, vol. 2, p. 259.

${ }^{58}$ Gohlman, op. cit., note 48 above, pp. 81-2.
}

\footnotetext{
${ }^{59}$ According to medieval medical ideas, inherited from the classical tradition, sexual indulgence caused a number of ailments, such as depression, tremblings, swelling of the stomach, physical weakness, or sight troubles, in addition to the shortening of life expectancy. See Danielle Jacquart and Claude Thomaset, Sexuality and medicine in the Middle Ages, Cambridge, Polity Press, 1988, pp. 118-19.

${ }^{60}$ Gohlman, op. cit., note 48 above, p. 83.

${ }^{61}$ Ibid., pp. 85-9.
} 


\section{Cristina Álvarez Millán}

the king of Gurgān whom no physician of the country had been able to cure. After having felt the patient's pulse and examined his urine, Ibn Sinnā asked for the assistance of someone who knew the cities of Gurgān very well. When the individual came in, following Ibn Sinā's instructions, he began to name the cities of Gurgān in front of the patient. At the mention of a given city, the physician felt the patient's pulse becoming extremely agitated. Ibn Sinā then asked that he name the streets of that town, and, as before, the patient's pulse increased when hearing a particular one. The process was repeated with the houses in that particular street and, again, with the inhabitants of a given house, so that Ibn Sīnā eventually-and successfully-diagnosed that the patient was in love with a young woman. The event happily ended in marriage and increased Ibn Sinā's reputation. ${ }^{62}$ However, historians have found many adaptations of this same story in Arabic and Persian settings, as well as a number of versions in Greek antiquity, ${ }^{63}$ with names changed but the details strikingly similar. Moreover, as with Ibn Zuhr's grapes for the Almohad ruler, it is likely that, had Ibn Sinā performed such a consultation, he (or his student) would not have failed to relate it in his biography. Consequently, this spectacular-but hardly original—case history falls within the realm of the story-telling genre elaborated not by Ibn Sīnā but by someone else.

Another story concerning Ibn Sinā's medical practice is to be found in the same Persian book. In this instance, the patient was a prince who, affected by melancholy, imagined himself to have been transformed into a cow and spent all day asking his servants to kill him to make good steaks with his flesh, and, as usual, his physicians had not been able to cure him. As the prince's request was obviously denied, he had stopped eating and had begun to waste away. While stressing Ibn Sinnā's high status and busy life as prime minister, the account lets us know how he humoured the patient impersonating a butcher and making him believe he was to sacrifice him as a cow, only to then postpone it with the excuse that the animal-the prince-was not fat enough. He prescribed the patient medicines and draughts saying that they were fatteners for cows, thus persuading the prince to eat, so that he soon recovered. ${ }^{64}$ Again, this entertaining account shares all the literary ingredients of a story-telling tradition which might perhaps be traced back to Greco-Roman physicians. More to the point, the nature of the mental disorder as much as the therapy employed in this literary story of madness and melancholy stand in sharp contrast to that found in real cases, such as those recorded in al-Rāzì's Kitāb alTajärib. ${ }^{65}$ Therefore, it would be unwise to consider it a real patient report, and to accept it as documentary evidence of medieval Islamic medical practice.

It should be recalled that Ibn Sīnā was engaged in many intellectual and professional activities other than medicine. In fact, out of forty-six works attributed to him, only

\footnotetext{
${ }^{62}$ See Edward G Browne, Chahār maqāalah ("Four discourses") of Nizámi-i- 'Arúdi' of Samarqand, London, printed by the Cambridge University Press for the Trustees of the E J W Gibb Memorial and published by Luzac, 1921, pp. 88-90.

${ }^{63} \mathrm{~J}$ C Bürgel, 'Psychosomatic methods of cures in the Islamic Middle Ages', Humaniora Islamica, 1973, 1: 157-72, esp. pp. 165-7; Luis García Ballester and Julio Samsó, 'Tradición y novedad en el galenismo árabe de los siglos IX y XI: la doctrina del pulso, el
}

pronóstico y un caso de aplicación de "masaje cardiaco",, Al-Andalus, 1972, 38: 337-51, esp. pp. 339-41; Helen King, Hippocrates' woman: reading the female body in Ancient Greece, London and New York, Routledge, 1998, p. 47.

${ }^{64}$ Brown, op. cit., note 62 above, pp. 91-3.

${ }^{65}$ For a description of cases dealing with mental disorders, see Álvarez Millán, op. cit., note 1 above, p. 296 


\section{The Case History in Medieval Islamic Medical Literature}

seven deal with medicine. ${ }^{66}$ According to his biography, we know that he spent his life as a court physician, at the service of rulers who appreciated his expertise. However, by contrast with al-Rāzì, there is no evidence that he worked in a hospital or in a setting in which a wider variety of patients and conditions would be encountered.

In Ibn Sīnā's medical works we find neither case histories from which general rules can be abstracted, nor accounts to support a theoretical discussion, nor experience on how to manage an anxious patient, nor first-hand advice on how to avoid fatal cases, and, more particularly, there are no treatments made specifically for certain patients tested or prescribed by the author, aside from recommendations or preferences for certain remedies. His discourse on how one might determine the efficacy of a pharmacological preparation is an excellent example of his application of logic to medicine, but no details are given of him, or anyone else, following those methods in the course of actual practice. ${ }^{67}$ What we do have is his disciple's statement in a biographical account that Ibn Sinna "carried out many consultations (tajārib)". In the same source we also find threeseemingly reliable — clinical references devoid of literary adornment, two being examples of self-treatment (one of which was disastrously unsuccessful) and the third involving treatment with a mixture of rose-honey with sugar.

Where does the myth of Ibn Sina as a successful and innovative practising physician come from? Questioning his image as a practising clinician should not diminish our admiration for his contribution as a theoretician, nor the value of humoral medicine as a medical system. For a wide audience he is the most representative physician of Islamic medicine. His influence on schools of medicine-both western and eastern-was primarily due to his skill as a systematizer of medical theory, his logical exposition of medical principles, and his gift as a writer of masterpieces such as the Qānūn. In the light of the scarce evidence of his clinical experience, it appears that his fame as a practising physician has been constructed on the basis of his medical writings, framed by a highly idealized view of medieval Islamic medical literature.

\section{Conclusion}

To conclude, medieval Islamic medicine has seldom been placed within the cultural and social setting in which it was practised, nor have many of the sources been critically examined. Learned medical knowledge was a sought-after product in flourishing urban societies, and learned medical treatises appear as a curricular requirement to enter the professional arena in prosperous courts. They were also part of the intellectual production funded by the ruling elites as an instrument for political propaganda. Although rhetoric and self-marketing is not incompatible with medical scholarship, medical literature-with or without case histories - seems to have been a physician's promotional tool in medieval Islam as much as in earlier and later periods. As Philip van der Eijk puts it

\footnotetext{
${ }^{66}$ Gohlman, op. cit., note 48 above, p. 47-9.

${ }^{67}$ See Mona Nasser, Aida Tibi, and Emilie Savage-Smith, 'Ibn Sīnā's Canon of medicine: 11thcentury rules for assessing the effects of drugs', $J$. $R$. Soc. Med., 2009, 102: 78-80 (originally published online in 'The James Lind Library' (http://www.
}

jameslindlibrary.org). For a somewhat overenthusiastic interpretation of this same text, see Mohammad M Sajadi, Davood Mansouri and Mohammad-Reza M Sajadi, 'Ibn Sīnā and the clinical trial', Annals of Internal Medicine, 2009, 150: $640-3$. 


\section{Cristina Álvarez Millán}

with regard to classical medicine, "the text is an instrument for scientists and practising physicians to define and assert themselves, to establish the position of their profession and to gain authority and power". ${ }^{68}$ A contextual approach to medieval Islamic medical literature shows that the same persuasive strategies were at work. It is clear that Galen's literary techniques for social and professional persuasion were known to many medieval Islamic medical writers and employed for the same purpose in their formal treatises. Non-medical sources such as biographical dictionaries and prosopography have successfully assisted them with the portrayal of exceptional individuals such as Ibn Sinā. Although case histories, clinical consultations and medical anecdotes can be a valuable source for historians of medicine, they must be carefully scrutinized for their context and validity in the same way that other documentary evidence must be weighed and evaluated.

\footnotetext{
${ }^{68}$ Philip J van der Eijk, 'Towards a rhetoric of ancient scientific discourse', in Egbert J Bakker (ed.), linguistic contexts, Leiden, Brill, 1997, pp. 77-129, Grammar as interpretation: Greek literature in its
} 